\title{
Baudelaire and the Chinese Object
}

Baudelaire's review of the Exposition Universelle of 1855 included a shocking attack on Ingres. His denigration of the seventy-five-year old champion of neo-classical painting arguably points to a new way of approaching Ingres's paintings in terms of their surreal artificiality, but it meant that this section of his review was deemed unpublishable at the time. In any case his polemical contrast of Ingres and Delacroix opens apparently indirectly, with a discussion of aesthetic relativism. Baudelaire's entry point into the Exposition is in fact via a display of Chinese objets d'art brought to France by Charles de Montigny, the first French Consul to Shanghai (1848-53). And from the outset his review of this first Paris World Fair takes a slant that is at odds with the occasion's nationalist celebration of technological progress. He also distances himself from the patriotic stance, inspired by Victor Cousin, which valorized French cultural "eclecticism," supposedly illustrated by the existence of rival schools around Ingres on the one hand and Delacroix on the other. In contrast, Baudelaire's discussion of a particular object in the musée chinois leads him towards an emphatic valorization of cosmopolitanism. ${ }^{1}$ The Chinese object of 1855 should not, however, be seen in isolation, and this paper will revisit its role in Baudelaire's aesthetics more generally. This Chinese art-object is in fact the meeting point for key strands of his thinking on aesthetic relativism, the bizarre, the comic, and the anti-natural.

On the surface, the period does not seem a propitious one for Franco-Chinese intercultural awareness. France's earlier cultural and philosophical engagement with the challenges posed by China, via the Jesuit missionaries of the sixteenth and seventeenth centuries, had declined over the course of the eighteenth century into a mere fad for chinoiserie. The term suggested a hackneyed form of decorative art that stood for superficiality, meaninglessness, and impenetrability. ${ }^{2}$ Chinese decorative objects and previously rare porcelain had become more 
common in European collections and indeed on European sideboards, and were also being copied locally, so that they had lost their prestige and status as unique pieces. Chinaware had come to embody the aspirations of the new middle classes. ${ }^{3}$ At the same time, China's power and international prestige were at a low ebb. ${ }^{4}$

Recent studies have however argued that chinoiserie exerted a "deeply ambivalent fascination" in the eighteenth century, when it was seen in a negative light in relation to the dominant neo-classical aesthetics, either as a monstrous defiance of beauty and nature, or as mere superficial prettiness. ${ }^{5}$ Building on Arthur O. Lovejoy’s famous argument, David Porter shows, however, that it was also linked to the emergence of a new aesthetics of the picturesque, the irregular, and the asymmetrical, which was to be crucial to the emergence of Romanticism in Britain. ${ }^{6}$ In eighteenth-century France, however, a reassertion of neoclassical aesthetics saw attacks on earlier sinophilia. When French Romanticism later began its long struggle with neo-classical aesthetics, Orientalism was one of the weapons it deployed, but for the 1830 generation this was not (yet) a Far-Eastern Orientalism. Victor Hugo's preface to Les Orientales (1829) is essentially a manifesto for the use of the Islamic Orient as a foil to classicism.

A generation later, it is however a Chinese art-object that Baudelaire uses in support of his own polemic against classical universalism. This may be partly a response to more general, if sporadic, signs of interest in China in the 1840 s and '50s, but as we shall see Baudelaire's stance differs significantly from that of his contemporaries.

In his review of the 1855 World Fair, his analysis offers little close description of the particular object that is supposed to have inspired it. Instead he asks how it would be seen by the great German pioneer of Art History, the theorist of neo-classical aesthetics, Johann Joachim Winckelmann: 
[Q]ue ferait, que dirait un Winckelmann moderne [...] que dirait-il en face d'un produit chinois, produit étrange, bizarre, contourné dans sa forme, intense par sa couleur, et quelquefois délicat jusqu'à l'évanouissement? Cependant c'est un échantillon de la beauté universelle... (OC 2:576). ${ }^{7}$

Baudelaire's "Winckelmann moderne" is one of the "modernes professeurs-jurés d'esthétique" or "doctrinaire[s] du Beau" (OC 2:577, his emphasis), perhaps a jibe at Victor Cousin but in any case an attack on the art establishment's continued adherence to neoclassical universalizing norms. In contrast, a form of aesthetic relativism had been pioneered by Herder, and along these lines Baudelaire's revisionist concept of "la beauté universelle" sees it as multiple. For him, the Chinese art-object is one "échantillon" among many forms of beauty. This was in fact a novel and provocative step: for the French Romantics, and indeed for most of the century, the dominant view of Chinese art (mostly known in the form of bibelots rather than painting) was that it was characterized by ugliness. It was thus as a representation of the ugly that chinoiserie was generally mobilized in the Romantic battle with classical good taste. Amid the chaos of the antique shop in Balzac's La Peau de chagrin (1831) — in many ways a philosophical World Fair avant la lettre — we find "Un monstre de la Chine dont les yeux restaient tordus, la bouche contournée, les membres torturés, [qui] réveillait l'âme par les interventions d'un peuple qui, fatigué du beau toujours unitaire, trouve d'ineffables plaisirs dans la fécondité des laideurs." ${ }^{\prime 8}$ In 1842 Balzac again describes Chinese art as ugly, though once again this is a form of praise: ugliness is inexhaustibly fertile, in contrast to beauty which is always the same, and necessarily repetitive. ${ }^{9}$

Théophile Gautier was to be the main conduit for the renaissance in aesthetic sinophilia in France, and apart from Baudelaire he was the only contemporary critic whose account of the 1855 exposition included a response to the Chinese exhibits. But he, like Balzac, continued to 
see Chinese art as ugly: "Les autres nations, à commencer par les Grecs qui l'ont atteint, cherchent le beau idéal; les Chinois cherchent le laid idéal." ${ }^{10}$ Although Gautier uses the term "génie bizarre" in relation to Chinese productions, he stresses the failure of the Chinese to produce museum-worthy art, and their extraordinary fecundity in producing saleable "bric-àbrac" (258). He effectively praises Chinese objects—vases, perfume-burners, and so on—at the expense of actual art. And this view was not to disappear quickly: in Pierre Larousse's Grand dictionnaire universel $d u X I X^{e}$ siècle, Chinese sculpture is still essentially summed up in the "magot" or small human figure, and seen as a caricature that is characteristically ugly (or grotesque, but as we shall see Baudelaire uses the term rather differently). ${ }^{11}$

Baudelaire, in contrast, sees Chinese art as reflecting the perfect correspondence or harmony of a national culture with its specific milieu and, at the same time, the perfect harmony of artistic form and function, although he doesn't say what the function of this particular object is. This idea of the meeting of form and function implies a very different view from that of Gautier, who gives a Chinese vase as an example of an object that is perfectly useless, and aesthetically agreeable for that very reason, in his manifesto of "l'art pour l'art," the preface to Mademoiselle de Maupin (1835). ${ }^{12}$ As seen by Baudelaire, in contrast, the Chinese object is neither useless nor ugly: it is part of the immense keyboard of universal correspondences, something to which the hypothetical professor of aesthetics is blind. ${ }^{13}$

Certainly, Baudelaire's attitude to China in his work as a whole is not without contradictions. At times he seems simply to be reiterating the stereotype, current at the time, in which the adjective "chinois" evoked needless and superficial complexity. ${ }^{14}$ Nevertheless, the Chinese object is part of Baudelaire's aesthetics of diversity, deployed in an argument against the supremacy of any one national form of art and against the ideology of progress. Already in 1846, he had written: "Chaque siècle, chaque peuple [a] possédé l'expression de 
sa beauté et de sa morale" and "tous les siècles et tous les peuples ont eu leur beauté" (OC 2:419, 493). In 1863, in Le Peintre de la vie moderne, Baudelaire builds on this attempt to establish a historicist theory of aesthetics, "en opposition avec la théorie du beau unique et absolu." His argument is, famously, that beauty is necessarily double, containing an eternal element and an "élément relatif, circonstanciel [...] qui est comme l'enveloppe amusante, titillante, apéritive, du divin gâteau" (OC 2:685). His focus here is to found a conception of modern beauty that would capture the fleeting moment, but in its opposition to the absolute, ahistorical beauty of classicism his argument draws on his earlier stance in favour of aesthetic relativism. The transience of modern beauty is derived directly from its engagement with singularity or the relative, circumstantial element. This dualism is also evoked in the image of the thyrsus, where the curved or arabesque line (one might almost call it the Chinese line) suggests the fantastic, singular element that combines with the straight line of eternal beauty. ${ }^{15}$

Although the brief discussion of the Chinese exhibits seems at first sight detached from the main argument of Baudelaire's Exposition universelle de 1855, it is indirectly a means of aligning himself with Delacroix against neo-classical aesthetics. It is in fact a response to Delacroix's own ideas as an art theorist. The latter had set out his theory of aesthetic relativism in articles in the Revue des deux mondes, one of which was published shortly before Baudelaire's 1855 piece. ${ }^{16}$ These are, then, ideas that were being discussed at the time by the artist Baudelaire most admired, and with whom he sought to be closely linked.

Aesthetic relativism is only part of Baudelaire's response to the Chinese object. The latter is also the pretext for his famous 1855 pronouncement that "Le beau est toujours bizarre," part of his argument against the ideal beauty of classicism and its "vaste unité, monotone et impersonnelle, immense comme l'ennui et le néant" (OC 2:578, his emphasis). ${ }^{17}$ Perhaps because there are conflicting accounts of the etymology of the word "bizarre"18 the concept 
has met with some critical disparagement. But Baudelaire's valorization of the "bizarre" is more significant, and more central to his aesthetics, than is acknowledged by Pierre Laforgue, for whom his 1855 pronouncement reflects a renunciation of any attempt at proper theorization and a fall into mere empiricism. The notion of the bizarre is, for Laforgue, so "flou" as to be perhaps "simplement ectoplasmique." He dismisses Baudelaire's attempt to theorize the bizarre as that which constitutes individuality as a "drôle de cuisine." He also sees the notion as disappearing after $1855 .{ }^{19}$ The term may indeed be less prominent, but the concept, on the contrary, appears both before and after 1855. In 1846 Baudelaire tells us that "l'idéal absolu est une bêtise" and that we would all be very unhappy if it were to be found (OC 2:455); and much later, in Fusées, his supposed "Journaux intimes," he notes: "Ce qui n'est pas légèrement difforme a l'air insensible; - d'où il suit que l'irrégularité, c'est-à-dire l'inattendu, la surprise, l'étonnement sont une partie essentielle et la caractéristique de la beauté" (OC 1:656). We find the same emphasis on surprise, or "l'étonnement," arising from a break with the strict rules of harmony, in 1855 , when it explicitly falls into the overall category of the bizarre (OC 2:578).

In Hugo's preface to Les Orientales classicism was already seen as hating "le désordre, la profusion, la bizarrerie, le mauvais goût," all aspects associated with the Orient, though not yet with China. ${ }^{20}$ This Romantic valorization of the bizarre was significantly at odds with earlier uses in art criticism, notably by Diderot. For him a painter only aims to produce the bizarre because of failure: "Quand on désespère de faire une chose belle, naturelle et simple, on en tente une bizarre." ${ }^{21}$ The Romantic concept of the bizarre is already linked to aesthetic relativism and divergence from a normative, single ideal of beauty, but it becomes more central to Baudelaire's thinking, perhaps in part because "bizarre" was the French equivalent of "odd," which he had encountered in Edgar Allan Poe's 1844 short story "The Angel of the Odd" and translated as "L'Ange du bizarre."22 In Baudelaire's translation the narrator relays 
the explanations of the titular angel: "Je ne prétends pas relater tout ce qu'il me dit; mais ce que j'en retins en substance, c'est qu'il était le génie qui présidait aux contre-temps dans l'humanité, et que sa fonction était d'amener ces accidents bizarres [in English "odd accidents"] qui étonnent continuellement les sceptiques." ${ }^{23}$ It is however in an earlier work by Poe, "Ligeia" (1838), of which he had published a translation in February $1855,{ }^{24}$ that Baudelaire found an aesthetic theorization of the strange: there Poe correctly attributes to Francis Bacon the assertion that "There is no exquisite beauty [...] without some strangeness in the proportion," though Poe's narrator makes some slight modifications ("exquisite" instead of Bacon's “perfect”). ${ }^{25}$ Baudelaire had published an account of Poe's life and works in 1852 , but in 1856 , not long after the 1855 exhibition, he published a second version in which he introduced the argument that Poe's "compositions étranges" "semblent avoir été créées pour nous démontrer que l'étrangeté est une des parties intégrantes du beau" ("Edgar Poe, sa vie et ses œuvres," OC 2:302).

Poe's ideas on the strange and the odd may well have fed into another aspect of Baudelaire's thinking in 1855 . That year he also published his article "De l'essence du rire." He declares himself to be obsessed by the topic of laughter, observing the presence of beauty “jusque dans les œuvres destinées à représenter à l'homme sa propre laideur morale et physique! Et, chose non moins mystérieuse, ce spectacle lamentable excite en lui une hilarité immortelle et incorrigible" (OC 2: 526). Alain Vaillant argues that the presence of comedy is a fundamental part of Baudelaire's conception of art, and hermeneutically essential to Les Fleurs $d u$ Mal. ${ }^{26}$ Michele Hannoosh, too, argues for the centrality of Baudelaire's essays on laughter and caricature in his aesthetic system more generally. ${ }^{27}$ Neither Vaillant nor Hannoosh, however, offer detailed discussion of the relationship between Baudelaire's theory of laughter and non-European cultures. In any case the comic, like the bizarre, is at the opposite end of the spectrum from the ideal of (Classical) Beauty expressed in the poem "La 
Beauté," where the latter declares that she never laughs: she gives voice to the monotonous, impersonal beauty that is rejected in Baudelaire's review of the 1855 World Fair.

Baudelaire stresses that comedy is located in the person who laughs, not in the object of the laughter. It becomes important, then, to distinguish Chinese art as seen by the Chinese (which is not comic) from Chinese art as seen by a European (which is comic). Chinese art was generally seen as being intentionally comic; for Balzac, for example, it is intended to make the viewer laugh ("La Chine et les chinois" 28-29). In contrast, in his essay on laughter Baudelaire argues that Chinese (and Indian) art is unconsciously funny: "Les idoles indiennes et chinoises ignorent qu'elles sont ridicules; c'est en nous, chrétiens, qu'est le comique" (OC 2: 534). In his theory self-aware laughter is postlapsarian, based on a satanic sense of superiority over others coupled with a sense of infinite lack of worth compared to the Absolute; this explosive combination is essentially Christian. This polemical argument appears to require him to see the (non-Christian) Chinese as being without a comic sense altogether, but the next stage in his theory introduces a different kind of humour.

Chinese art is in fact held up as representing another, more fundamental kind of humour, in contrast to the Christian-derived form of laughter. Whereas ordinary laughter is caused by "le comique de mœurs" or a sense of superiority over others, this is distinct from "le comique absolu," which is aligned with the grotesque. Laughter of this kind arises from a mixture of elements that exist in nature, and 'dans ce cas-là le rire est l'expression de l'idée de supériorité, non plus de l'homme sur l'homme, mais de l'homme sur la nature" (OC 2:535). The idea that Chinese art offers an example of "le comique absolu" arising from a sense of superiority over nature may already be implicit in the Salon de 1845 where, quoting Heine, Baudelaire describes China as a place "où la nature et l'homme ne peuvent pas se regarder sans rire."28 
The characteristic naivety of the "comique absolu"—its quality "de s'ignorer lui-même" — can be seen "dans les monstruosités chinoises qui nous réjouissent si fort, et qui ont beaucoup moins d'intentions comiques qu'on ne le croit généralement. Une idole chinoise, quoiqu'elle soit un objet de vénération, ne diffère guère d'un poussah ou d'un magot de cheminée" $(O C$ 2:542). This lack of self-awareness is a characteristic of the "comique absolu" or grotesque just as it is of the bizarre in the form that is most conducive to beauty, that is, a "bizarrerie naïve, non voulue, inconsciente" (OC 2:578). Without this naivety the bizarre becomes coldly calculating, and the comic too controlled. While it might seem surprising for Baudelaire to stress lack of self-awareness, since the Chinese object could be seen as self-consciously taking a disjunctive relation to Nature, this fits with his praise of spontaneity and naivety, "l'enfance retrouvée à volonté" (in "Le Peintre de la vie moderne," OC 2:690, his emphasis). Michele Hannoosh suggests, moreover, that the spontaneous laughter aroused by the comique absolu in fact "guarantees a sense of inferiority alongside superiority, preserving the ironic dualism on which self-knowledge depends. For the loss of control represented by its explosive, sudden laughter signals the presence of a force beyond our conscious comprehension $[\ldots]$ And the nature to which we feel superior is also that in which we must live" (40). Baudelaire himself points out the subtlety of his assertion, adding that although the grotesque might seem knowing, it is in some ways deeper, more primitive, and closer to the innocence of pure joy, than is the "comique des mœurs" (OC 2:535).

The association of China with the unnatural was generally seen in an extremely negative light. It is no coincidence that the cruel disfigurement of a child in Victor Hugo's novel L'Homme qui rit (1869) is compared to a supposedly Chinese technique that is a horrific deformation of nature. In a more playful mode, Gautier's response to the 1855 Chinese exhibition, though it appears to celebrate the rejection of nature by Chinese art, in fact does so half ironically: 
[Les Chinois] pensent que l'art doit s'éloigner autant que possible de la nature, inutile selon eux à représenter, puisque l'original et la copie feraient double emploi. La belle malice de rendre les choses comme elles sont! et le rare effort d'imaginative [sic]! Ce n'est pas ainsi qu'un artiste prouve sa puissance créatrice; mais composer un monstre qui ait les apparences de la vie, inventer des paysages chimériques, peindre de couleurs fictives des êtres imaginaires, faire tenir dans le même cadre des objets que la perspective sépare, voilà à quoi un maître se reconnaît. Et puis le laid est infini [...] (258)

Even the champion of l'art pour l'art partially deprecated an art that was seen as unnatural, or even anti-natural. In Baudelaire's anti-Rousseauist aesthetics, on the other hand, nature is rejected and virtue is artificial ("Éloge du maquillage," $O C$ 2:715). So although he too sees Chinese art as departing from nature, the trait is given an essentially positive valorization in his system. The Chinese sensibility is the exact opposite of the figure of Virginie as imagined by Baudelaire, a soul "sortant, pour ainsi dire, des mains de la nature" and thus incapable of laughter (OC 2:528). And as we have seen, it is man's belief in his superiority to nature that gives rise to the grotesque. While the simple comique is "une imitation," the grotesque or comique absolu (and by implication Chinese art) is "une création" (OC 2:535). This is to be understood in the context of Baudelaire's fundamental affirmation of the superiority of art over nature, closely linked to his ideal of "surnaturalisme" (OC 1:658).

The view of China as a land of artifice was a late turn in a meandering intercultural history. In the seventeenth, and into the eighteenth century, Chinese gardens were on the contrary celebrated for their use of natural forms, irregularity and, by extension, the picturesque. Chinese aesthetics were thus seen as offering a space for fantasy and became a 
pretext for playful asymmetry, surprise, and expressivity in gardening styles, in contrast with the rigid neoclassical forms of the Italian or French garden. Lovejoy's argument that Chinese aesthetics were one of the origins of Romanticism specifically focuses on the style of gardens associated in France with le goût anglo-chinois, and which was to evolve into the jardin anglais. But although the irregularity and elements of surprise in Chinese style were initially seen as an imitation of nature, these came in time to be seen as an exaggeration of nature (Lovejoy 102, 114). By the time Baudelaire picks up the thread, Chinese art has come to stand for distance from nature.

It is thus a knowing manipulation of nature that Baudelaire celebrates by comparing Holland to China in the prose "Invitation au Voyage" (OC 1:301-03) ${ }^{29}$ In Amsterdam "la fantaisie a bâti et décoré une Chine occidentale." This "pays singulier" (repeated) is “supérieur aux autres, comme l'Art l'est à la Nature, où celle-ci est réformée par le rêve, où elle est corrigée, embellie, refondue." One could call it "l'Orient de l'Occident, la Chine de l'Europe, tant la chaude et capricieuse fantaisie s'y est donné carrière, tant elle l'a patiemment et opiniâtrement illustré de ses savantes et délicates végétations." The key role of Chinese influence on garden style helps to explain Baudelaire's reference in this passage to sophisticated, knowing "végétations." He implies a process and not simply a product, like the artificial horticulture that strives to produce the unnatural flowers (the "tulipe noire" and "dahlia bleu") of the same prose poem. Although on the surface this land is characterized by calm and order, the contradiction with Baudelaire's aesthetic valorization of surprise merely confirms the speaker's irony in claiming that the exotic land, like the woman who resembles it, is "beau, riche, tranquille et honnête". ${ }^{30}$ The repetition of these adjectives, and the comparison of this rich cleanliness with both gleaming pots and pans and "une belle conscience," comically undermines the assertions even as they are made. 
Barbara Johnson reads the prose "Invitation au voyage" essentially as a dialogue with the verse version, and the "pays singulier" as exemplifying poetry itself transformed into prose. ${ }^{31}$ But in a more general sense it is the creation of art rather than the passive acceptance of nature that can be seen as embodied in this anti-natural Occidental China.

Bringing nature into the frame is not in fact a new turn in my argument: it is the flipside of my earlier point that Baudelaire was positioning himself against universalist aesthetics. Although nature might seem infinitely diverse to us now, in the nineteenth century and earlier an aesthetics derived from nature was often aligned with a single, universal ideal, albeit one that was not absolutely to be identified with the classical ideal. For the German theorists Lessing and Schiller, critical of Winckelmann's neo-classicism, nature, and not classical sculpture, was the source of eternal principles. But Baudelaire, mounting his own argument against classical universalism, could not use nature as an ideal since he rejected its valorization by earlier Romanticism. He needed some other positively valued pole to oppose to both classical idealism and the cult of nature. This is what, in 1855 , he calls the "bizarre."

In his account of the 1855 exhibition, he follows his attack on Ingres with a startling digression on the painter who was the subject of intense polemic that year, and whose paintings had been refused by the exhibition: Courbet. In a self-consciously paradoxical move he draws a parallel between Ingres and Courbet, those apparent opposites. Ingres's idealism and Courbet's realism are antithetical forms of fanaticism that declare war on the imagination; they are both "anti-surnaturalistes" (OC 2:585-86). The Chinese object is not, then, a randomly chosen point of entry into the World Fair: it is a symbol that is both antiIngres and anti-Courbet, the polar opposite of both the unique neoclassical ideal and the slavish imitation of nature. It is what one might call an example of surnaturalisme bizarre. As Baudelaire had already argued in 1846, true art lies not in an excess of generality and the pursuit of a geometrical (purely classical) perfection, nor in the slavish copying of nature. In 
the "lutte entre la nature et l'artiste" the artist will triumph if he understands the intentions of nature and translates them into a simpler and more luminous language, one that will capture the internal harmony of the subject matter ("De l'idéal et du modèle," OC 2:457).

Baudelaire's valorization of the Chinese object is, as I have suggested, a development of the Romantic aesthetics of singularity. His concept of the "bizarre" is tightly bound up with this cultural relativism: "bizarrerie, nécessaire, incompressible, variée à l'infini, dépendante des milieux, des climats, des mœurs, de la race, de la religion et du tempérament de l'artiste" (OC 2:578-79). As we have seen, the Chinese object is in fact deployed by him as part of a double attack: on the one hand against neo-classical universal aesthetics, and on the other against slavish adherence to nature.

He also takes this relativist conception of beauty one step further, briefly suggesting what a truly cosmopolitan gaze would be. In contrast with those who consider Chinese art to be ugly because it does not conform to neo-classical norms, he describes the need for an understanding of foreign art that is much more demanding. It requires an extraordinary act of the will to transform the imagination so that the viewer might see with the eyes of another culture. Possessing such a cosmopolitan gaze by a sort of "grâce divine" is rare, but it can be acquired by anyone, to some extent. A cultivated man living in a distant country would, after a long time and great effort, reach an intimate understanding of the "harmonies nouvelles" of its life and art. The difficulty of achieving this new intercultural perception is evoked by the comparison with a solitary traveller who leaves behind his own culture and, stripped bare of preconceived ideas, is thus able to respond to a new one (OC 2:576-77). Baudelaire's view of art as arts in the plural in the Exposition Universelle predicates something like an anthropologist engaged in participant observation avant la lettre. True aesthetic relativism is 
a form of cosmopolitanism that requires one to see empathetically through another's eyes, via an act of radical "self-transformation" or "willful doubling." 32

Baudelaire's ideal of aesthetic cosmopolitanism is quite at odds with the stereotype of the "impenetrable" Chinese who resist all understanding. Current in the nineteenth century, this cliché was to have a long life in Western thinking. A century later Sartre denounces the stereotype that "l'âme chinoise" is "impénétrable" and characterized by "les idées [...] courbes" whereas French ideas are seen as "droites." ${ }^{, 33}$ For Baudelaire, on the contrary, it is possible - with effort, time, and a partial abandonment of one's own cultural norms- to achieve a truly intercultural aesthetic vision. Seeing with other people's eyes is not seeing their art as impenetrable, but on the contrary being penetrated by it: constructing, laboriously, a sympathy that will be "si pénétrante" that it will create a whole world of new harmonies "[qui] entrera lentement en lui, le pénétrera patiemmment," transforming the viewer irrevocably (OC 2:576-77).

\footnotetext{
${ }^{1}$ Margueritte Murphy, "The Critic as Cosmopolite: Baudelaire's International Sensibility and the Transformation of Viewer Subjectivity," in Art and Life in Aestheticism: De-Humanizing and ReHumanizing Art, the Artist, and the Artistic Receptor, ed. Kelly Comfort (Palgrave Macmillan, 2008), 25-26, and "Becoming Cosmopolitan: Viewing and Reviewing the 1855 Exposition Universelle in Paris," Nineteenth-Century Contexts 32, no. 1 (2010): 31-46. This is also discussed by Timothy Raser, "The Politics of Art Criticism: Baudelaire's Exposition universelle", Nineteenth-Century French Studies 26, no. 3-4 (1998): 336-45.

${ }^{2}$ David Porter, "Chinoiserie and the Aesthetics of Illegitimacy," Studies in Eighteenth-Century Culture 28 (1999): 27-54. On the decline of the earlier "sinophilism" in the last decades of the eighteenth century, see J.J. Clarke, Oriental Enlightenment: the Encounter between Asia and Western Thought (London: Routledge, 2003), 52, and chapter three more generally.

${ }^{3}$ Ting Chang, Travel, Collecting, and Museums of Asian Art in Nineteenth-Century Paris (Farnham: Ashgate, 2013), 124.

${ }^{4}$ France had forced China to sign a trade agreement in 1844 (the Huangpu or Whampoa treaty) and was soon to go to war, alongside Britain, in order to protect the French right to sell opium to China (the "Second Opium War" of 1856-60).

${ }^{5}$ David Porter, "Monstrous Beauty: Eighteenth-Century Fashion and the Aesthetics of the Chinese Taste," Eighteenth-Century Studies 35, no. 3 (2002), 395, 402-03.

${ }^{6}$ Arthur O. Lovejoy, "The Chinese Origin of a Romanticism" [1933], Essays in the History of Ideas (Baltimore: Johns Hopkins University Press, 1948), 99-135, and David Porter, The Chinese Taste in Eighteenth-Century England (Cambridge University Press, 2010).

${ }^{7}$ Baudelaire's polemic against the influence of Winckelmann and neo-classical idealism is discussed in more detail in my article "'La Beauté': Art and Dialogism in the Poetry of Baudelaire," forthcoming in Neophilologus. 102:1 (2018) 1-14.
} 
${ }^{8}$ La Peau de chagrin, ed. Pierre Citron, in Balzac, La Comédie humaine, vol. 10 (Paris: Gallimard, 1979), 71, my emphasis.

${ }^{9}$ Honoré de Balzac, "La Chine et les chinois," reprinted in Le Courrier Balzacien 21-22 (2012), 7 39 (p 28). First published in La Législature, Oct. 14, 15, 17, 18, 1842, this playful riff is ostensibly a book review of a publication by the painter Auguste Borget.

${ }^{10}$ Théophile Gautier, "Exposition universelle de 1855," in Euvres complètes. IV-Critiques d'art. Les Beaux-Arts en Europe - 1855, ed. Marie-Hélène Girard (Paris: Honoré Champion, 2011), p. 258. Gautier's article first appeared as "L'Art chinois" in L'Artiste, Oct. 7, 1855, and was reprinted in 1857 in his collection of writings on the 1855 exhibition under the heading "Collection chinoise." See also Murphy 28.

${ }^{11}$ Pierre Larousse, Grand dictionnaire universel du XIXe siècle (Geneva: Slatkine Reprints, 1982 [1866-79]), article "Chine," vol. 4, part 1, 134.

${ }^{12} \mathrm{He}$ states his preference for a "vase chinois, semé de dragons et de mandarins" over a useful "vase" (chamber pot). Mademoiselle de Maupin (Paris: Garnier, 1966), 24.

${ }^{13}$ Baudelaire's audacity in seeing Chinese art as an example of universal beauty was pointed out, albeit briefly, by Yoshio Abé ("Le Beau est toujours bizarre," Le Monde, Nov. 28, 1968, 22). Abé argues that critics have tended to read the famous claim about the aesthetics of the odd exclusively in relation to refined fin-de-siècle decadence, and that this ignores Baudelaire's emphasis on the naive and childlike spontaneity of the true bizarre.

${ }^{14}$ The adjective "chinois" is used in a stereotypically deprecating way in Baudelaire's reference to Ingres's "bariolages persans et chinois" (OC 2:588). Striking a more Gothic note, in his translation/account of De Quincey's opium eater, China, "bizarre et artificielle" oppresses the hallucinating addict in the form of a mysterious Malay (OC 2:483); the difference between different parts of East Asia seems entirely lost. The adjective is also used in a stereotypically deprecating way in reference to Ingres's "bariolages persans et chinois" (OC 2:588).

15 "Le Thyrse" (OC 1:335-36). On Edgar Allan Poe's related use of the "arabesque" to signal fantasy, see Eric Lysøe, "D'Orient? D'Occident? L'arabesque selon Poe", in Orients littéraires. Mélanges offerts à Jacques Huré, ed. Sophie Basch, André Guiyaux and Gilbert Salmon (Paris: Champion 2004), 283-305.

${ }^{16}$ Eugène Delacroix, "Questions sur le Beau," La Revue des Deux Mondes (Jul. 15, 1854) and "Des Variations du Beau," Revue des Deux mondes (Jul. 15, 1857), republished in Delacroix, Euvres littéraires, ed. Élie Faure, I: Études esthétiques et II: Essais sur les artistes célèbres (Paris: Éditions G. Crès et Cie, 1923), 23-36 and 37-54.

${ }^{17}$ In his 1854 article Delacroix also uses the word "bizarre," in discussing Michelangelo's art, which he says is excluded by the doctrine of formal regularity (28).

${ }^{18}$ The word entered French in the sixteenth century as bigearre, from the Italian for "capricious" or "irascible," the Spanish for "brave," or the Basque for "bearded." The most plausible explanation may be that it comes from the Spanish for "brave": when Spanish soldiers in France in the sixteenth century called themselves caballeros bizarros the French just thought they were odd, i.e. foreign. The word rapidly took on the meaning of something that diverged from the habitual, and was adopted into English from the French in the seventeenth century. Very close in meaning to singulier, it signifies “qu'un objet est seul de son espèce, qu'il n'a pas de semblable; l'esprit en tire souvent la conséquence qu'on y trouve quelque chose de bizarre ou d'étrange, mais le mot ne signifie cela que d'une manière indirecte." (Larousse, Grand dictionnaire universel du XIXe siècle, article "Bizarre", vol. 2, part 2, 781). For a more general discussion of how the "bizarre" was received see Régine Borderie, "Bizarre," "Bizarrerie": De Constant à Proust. Essai (Grenoble: ELLUG, 2011).

${ }^{19}$ Pierre Laforgue, "D'une esthétique du bizarre chez Baudelaire: 1'Exposition universelle de 1855," in Autour de Baudelaire et des arts: Infini, échos et l imites des correspondances, ed. Fayza Benzina (Paris: L'Harmattan, 2012), 319. His argument is that Baudelaire abuses the notion of the bizarre in order to avoid discussing Realism, which was the hot topic of 1855. In Ut pictura poesis: Baudelaire, la peinture et le romantisme (Presses universitaires de Lyon, 2000). Laforgue sees Baudelaire's comments on the bizarre as so flexible that they reveal a refusal to take a position (180).

${ }^{20}$ Victor Hugo, Les Orientales, ed. Pierre Albouy (Paris: Gallimard, 1966), 22. Later in the century chinoiserie is almost synonymous with "bizarrerie," as well as "mauvais goût," in common 
usage (see article "Chinoiserie" in Larousse, Grand dictionnaire universel du XIXe siècle, article "Chine," vol. 4, part 1, 139).

${ }^{21}$ Salon de 1765, in Denis Diderot, Euvres, vol. 4 (Esthétique-Théâtre), ed. Laurent Versini (Paris: Robert Laffont, 1996), 340.

${ }^{22}$ First published in La Presse, Feb. 17, 1860, and then in Histoires grotesques et sérieuses (1865). Baudelaire's discovery of Poe dates to 1847 , with a first translation in 1848, but his interest appears to have been most intense in the 1850s (see notes in $O C 2: 1200-02$ ), so around the same time as the Exposition Universelle.

${ }^{23}$ Edgar Allan Poe, Histoires grotesques et sérieuses, trans. Charles Baudelaire (Paris: Michel Lévy frères, 1865), 200. Italics in the original English and in Baudelaire's translation. One might link this "génie [des] contre-temps" to the "Démon du contretemps" in the prose poem "L'Horloge" (OC 1: 300), first published in 1857.

${ }^{24}$ Le Pays, Feb. 3 and 4, 1855.

${ }^{25}$ The Works of the Late Edgar Allan Poe, ed. Rufus Wilmot Griswold, vol. 1 (New York, J.S. Redfield, 1850), 454, Poe's emphasis.

${ }^{26}$ Baudelaire, poète comique (Presses Universitaires de Rennes, 2007).

${ }^{27}$ Michele Hannoosh, Baudelaire and Caricature: From the Comic to an Art of Modernity (Pennsylvania State University Press, 1992), 3.

${ }^{28}$ Baudelaire was discussing the painter of Chinese scenes, Borget. "Les tableaux de M. Borget nous font regretter cette Chine où le vent lui-même, dit H. Heine, prend un son comique en passant par les clochettes, - et où la nature et l'homme ne peuvent pas se regarder sans rire" (OC 2: 394). The reference is to Heine's Über Deutschland: "Mensch und Natur können dort einander nicht ohne innere Lachlust ansehen." See http://www.china-institut.org/china-damals/heinrich\%20heine.htm (accessed Jan. 29, 2017). This can be translated as "Man and Nature cannot look at each other without an urge to laugh." Heine goes on: "But they do not laugh aloud, as they are both too civil; and to suppress the laughter they cut the most seriously comical faces." (With thanks to Gabi Duigu for the translations.)

${ }^{29}$ The prose version of "Invitation au voyage" was first published in Le Présent, 24 August 1857, with the mid 1850s, once again, a likely peak in Baudelaire's interest in the bizarre and the unnatural. The verse version was published in the Revue des Deux Mondes, 1 June 1855, though it was probably written earlier.

${ }^{30}$ See J.A. Hiddleston, Baudelaire and Le Spleen de Paris (Oxford: Clarendon Press, 1987), 70, on the undermining of lyricism by a "deflating epithet such as "honnête" applied to the exotic dream of a European China."

${ }^{31}$ Barbara Johnson, Défigurations du langage poétique: La seconde révolution baudelairienne (Paris: Flammarion, 1979), 152.

${ }^{32}$ On "transformative cosmopolitanism" see Murphy 35; on cosmopolitanism and the doubling of the self see Hannoosh 288-99.

${ }^{33}$ Jean-Paul Sartre, "D'une Chine à l'autre," in Situations V: Colonialisme et néo-colonialisme (Paris: Gallimard, 1964), 7-8. 